\title{
A Gene-enriched BAC Library for Cloning Large Allele-specific Fragments from Maize: Isolation of a $240-k b$ Contig of the bronze Region
}

\author{
Huihua Fu and Hugo K. Dooner ${ }^{1}$ \\ The Waksman Institute, Rutgers University, Piscataway, New Jersey 08855 USA
}

\begin{abstract}
A generic bacterial artificial chromosome (BAC) library from a complex plant genome like maize may not be suitable for some types of genomic analysis, for example, for establishing correlations between the genetic and the physical organization of a given chromosome region. Previously, we carried out extensive genetic analysis of the bronze $(B z)$ region in Zea mays using a W22 inbred line carrying the $B z-M c C$ allele; however, BAC libraries of that line are neither available nor under construction. Here, we report the isolation of large, adjacent BAC clones of this region from a partial BAC library of W22. We developed a BAC vector suitable for cloning Notl fragments and used it to clone size-fractionated genomic DNA that had been cut to completion with the methylation-sensitive, rare-cutting enzyme Notl. This strategy resulted in a very significant enrichment of large genic DNA. From a library of about 20,000 BACs, containing just two-thirds of a maize genome, we isolated 16 $\mathrm{BAC}$ clones of the $110-\mathrm{kb}$ distal $\mathrm{Bz}$ fragment and $10 \mathrm{BAC}$ clones of the $130-\mathrm{kb}$ proximal $\mathrm{Bz}$ fragment. This recovery means that our strategy resulted in a 15- to 24-fold enrichment of specific sequences. The order of the BAC clones in the $240-\mathrm{kb}$ contig, predetermined from an internal Notl site in the $B z-M c C$ allele was confirmed by hybridization with sequences from sites previously mapped proximal and distal to $B z$ and by sequencing. To show the general utility of our approach and the value of our partial BAC library, we also isolated BAC clones of other sequences, such as tub4 and the complex $R-r$ allele, contained in the same size fraction of DNA. This is the first report of the use of a BAC vector to clone allele-specific large DNA fragments from a plant with a large genome, circumventing the need to construct a complete BAC library.
\end{abstract}

Genetic background is a critical, yet often overlooked, experimental parameter. In extreme instances, erroneous conclusions about the phenotypic effect of a mutation may be reached from ill-advised comparisons of wild-type and mutant phenotypes in different genetic backgrounds. A more recent trap facing geneticists is to assume that genomic organization is a constant in different genetic backgrounds. Because the type of resource required for genomic analysis - a library of large DNA fragments-is difficult to generate, the temptation to ignore the genetic source of the library is great and increases with genome size.

Bacterial artificial chromosomes (BACs) (Shizuya et al. 1992) have become the vectors of choice for cloning large (>100 kb) DNA fragments from plants. To date, BAC libraries have been constructed for several plants: Arabidopsis (Mozo et al. 1998), rice (Wang et al. 1995; Xu et al. 1998), sorghum (Woo et al. 1994), tomato (Hamilton 1997), sugarcane (Tomkins et al. 1999b), and soybean (Tomkins et al. 1999a). Because of the effort required to construct a complete BAC library of organisms with large genomes, such libraries are being developed either by commercial concerns or specialized genome centers. Maize has a large genome (2.5 $\times 10^{9}$ bp; Arumuganathan and Earle 1991) and is

'Corresponding author.

E-MAIL dooner@waksman.rutgers.edu; FAX (732) 445-5735. highly polymorphic (Walbot and Messing 1988). Assuming an average insert size of $100 \mathrm{~kb}$, almost 300,000 colonies would be required for an 11-fold representation of the haploid maize genome, the level of redundancy of the Nipponbare BAC library being used in the rice genome project (Budiman et al. 1999). The only maize libraries currently available are based on the inbred line B73 and are considerably shallower than the existing rice or Arabidopsis libraries, although deeper libraries based on the inbred lines B73 and LH132 will soon be publicly available (R. Wing, pers. comm. and http://www.genome.clemson.edu/lib frame.html).

Our laboratory has a long-standing interest in the relationship between genetic and physical distance in the $B z$ region of the short arm of chromosome 9 (9S). We have shown that the $B z$ gene is at least 100 times more recombinogenic than the average segment of the maize genome (Dooner 1986; Dooner and MartinezFerez 1997) and are interested in studying recombination immediately outside of $B z$. To achieve this goal, we need to isolate and analyze large DNA fragments corresponding to defined genetic intervals on the proximal and distal side of the $\mathrm{Bz}$ locus. A possible source of these fragments is the existing BAC library from the inbred line B73. However, all our previous work on intergenic recombination in the region has 
been carried out with a different genetic line, namely a version of the W22 inbred line carrying an introgressed $\mathrm{Bz}-\mathrm{McC}$ allele (Dooner and Belachew 1989). Because of the extensive DNA polymorphisms in maize, we were concerned that the $\mathrm{Bz}$ region in B73 might differ from that in the $B z-M c C$ version of $\mathrm{W} 22$ and, as it turned out, our initial concern proved justified. We analyzed a $\mathrm{Bz}$ BAC clone from a commercially available B73 BAC library (kindly provided by Dr. V. Llaca) and found that the makeup of the DNA distal to $\mathrm{Bz}$ in that clone differed substantially from that in a previously isolated $\lambda$ clone of the $\mathrm{Bz}-\mathrm{McC}$ allele (Ralston et al. 1988; $\mathrm{H}$. Fu and H.K. Dooner, unpubl.). Thus, to make a proper comparison, it became necessary for us to isolate the $B Z$ region from the line used in our genetic experiments.

We were neither interested in nor in a position to construct a complete BAC library of our W22 maize line, so we decided to try to isolate large fragments of the $B z$ region from a partial library highly enriched in the fragments of interest. That is, we set out to use BAC vectors in much the same way that $\lambda$ phage vectors have been used to construct partial libraries of sizefractionated DNA from total genomic digests. To that end, we modified pBeloBAC 11 (Fig.1; Kim et al. 1996a) to make it suitable for cloning NotI fragments. We chose the restriction enzyme NotI because it has an 8-bp recognition sequence and is sensitive to cytosine methylation. Consequently, it cuts maize DNA infrequently. Furthermore, NotI cuts once within Bz-McC (Ralston et al. 1988), producing a Bz-proximal and a $B z$-distal fragment, which can be aligned and oriented

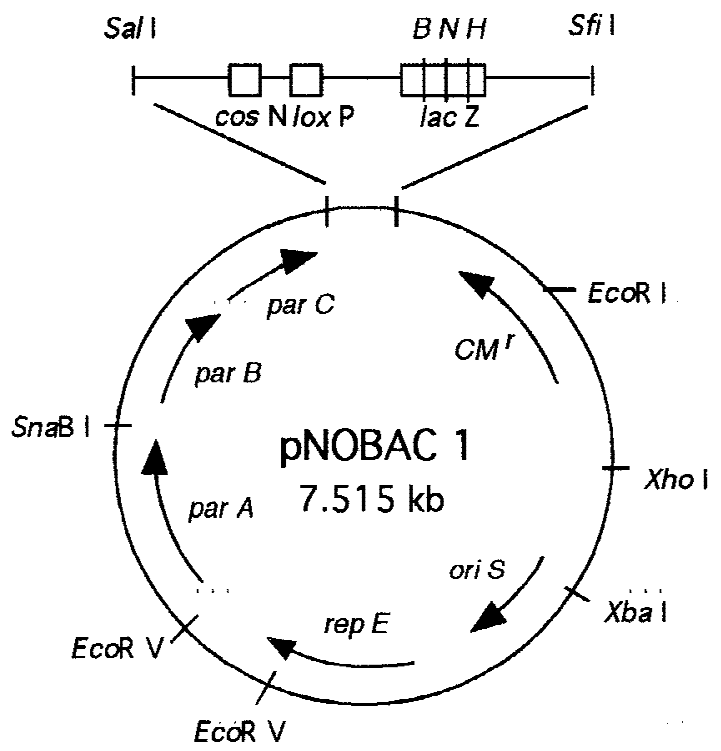

Figure 1 Schematic representation of the PNOBAC 1 vector. pNOBAC 1 is a Notl cloning BAC vector derived from pBeloBAC 11 (Kim et al. 1996b). It lacks the two Notl sites located on either side of the lacZ gene in pBeloBAC 11, has a new Notl cloning site between BamHI and HindIII in the polylinker, and retains the blue-white selection feature of its progenitor.

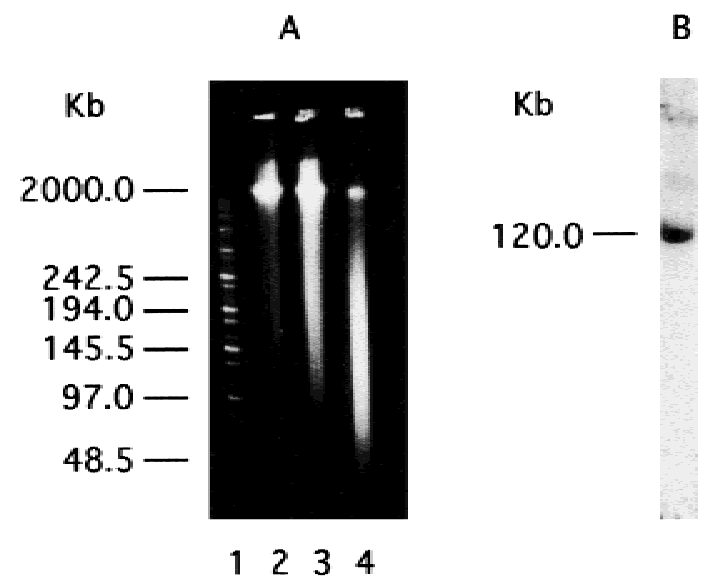

Figure 2 CHEF gel electrophoresis of maize genomic DNA. (A) Ethidium bromide-stained gel of maize genomic DNA that was not digested (lane 2) or was digested with either Notl (lane 3) or Sfi I (lane 4). (Lane 1) DNA size markers. (B) Autoradiogram of a different gel containing Notl-digested maize DNA. The membrane was hybridized with the probe Bz-528 (see Fig. 3).

along the known $\mathrm{Bz}-\mathrm{McC}$ sequence. Here, we report the successful implementation of our strategy in the cloning of adjacent $\mathrm{Bz}$ fragments, which together comprise a $240-\mathrm{kb}$ contig of the $\mathrm{Bz}$ region in $9 \mathrm{~S}$. We also isolated a $140-\mathrm{kb}$ tub4 and a $180-\mathrm{kb} R$ clone from the same partial BAC library, thus demonstrating the general utility of our approach. This is the first report of the use of a BAC vector to clone allele-specific large DNA fragments from a plant with a large genome, thus bypassing the daunting task of having to construct a complete BAC library when such a library is not needed.

\section{RESULTS}

\section{A BAC Vector Suitable for Cloning Notl DNA Fragments}

A large fraction of the maize genome consists of methylated, repetitive DNA (Hake and Walbot 1980; Bennetzen et al. 1994) that is not cut by methylationsensitive enzymes. In contrast, most genes exist in hypomethylated CpG islands (Antequera and Bird 1988). The enzyme NotI cuts maize DNA infrequently because it recognizes an 8-bp sequence, GCGGCCGC, and is sensitive to cytosine methylation. As seen in Figure $2 \mathrm{~A}$ lane 3, a complete NotI digest of maize DNA produces very large fragments, most of which are larger than 2 $\mathrm{Mb}$ and cannot be resolved in a conventional CHEF gel. In contrast, Sfi I, another octanucleotiderecognizing enzyme which is less sensitive to cytosine methylation, produces smaller DNA fragments with an average size around $130 \mathrm{~kb}$ (Fig. 2A, lane 4).

Probing a NotI digest of DNA from the W22 Bz$\mathrm{McC}$ maize line with a $\mathrm{Bz}$ probe that contains an internal NotI site (Bz-528 in Fig. 3) produces a thick band (Fig. 2B) that can be resolved into two bands of very 


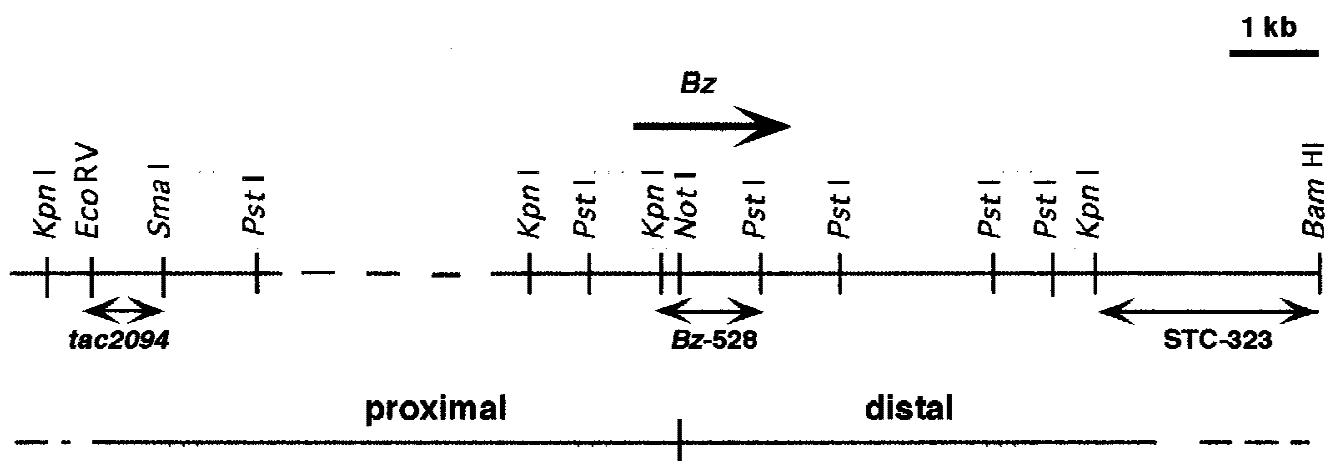

Figure 3 Partial restriction map of the $B z-M c C$ and $A c 2094 \lambda$ genomic clones (Ralston et al. 1988, 1989). (Large arrow) Location and orientation of $B z$ transcript; (double-headed arrows) locations and extents of the three probes used in this work, Bz-528, STC-323, and tac2094. The Notl site in the Bz-528 fragment divides the Bz-McC gene into a proximal and a distal fragment, as shown (Dooner et al. 1985).

similar size $(\sim 110 \mathrm{~kb})$ if the gel is run longer under different electrophoresis conditions (not shown). Thus, digestion of genomic DNA with NotI followed by CHEF gel fractionation of fragments in the 100- to 180$\mathrm{kb}$ range should provide a very significant enrichment of both $\mathrm{BZ}-\mathrm{McC}$ fragments and allow their BAC cloning without having to construct an entire BAC library.

To be able to clone NotI fragments into a BAC vector while retaining the bacterial colony color discrimination feature of existing BAC vectors, we modified pBeloBAC 11 (Kim et al. 1996a) as described in Methods. The resulting vector, pNOBAC 1 (Fig. 1), lacks the two NotI sites located on either side of the lacZ gene in pBeloBAC 11 and has a new NotI cloning site between $B a m H I$ and HindIII in the polylinker.

\section{Isolation of Proximal and Distal Bz Clones from a Partial BAC Library}

A partial BAC library of about 20,000 colonies was constructed from $B z-M c C$ DNA that had been digested completely with NotI and enriched for fragments in the 100 - to $180-\mathrm{kb}$ range. The bacterial colonies were transferred to a nylon membrane and hybridized with a labeled 1.2-kb KpnI-PstI fragment from Bz-McC (Bz-528 in Fig. 3: Ralston et al. 1988), which contains an internal NotI site 180 bp downstream of the KpnI site. Seventeen clones giving the strongest signals in the colony lift were isolated. BAC DNA from these positive clones was extracted, digested with NotI, and analyzed on pulsed-field gels. Figure 4A shows the ethidium bromide stain of a CHEF gel containing DNA from five positive clones (lanes 2-6), one negative control clone (lane 7), and high-molecular-weight markers (lane 1). Two patterns can be distinguished among the positive BAC clones: one given by the BAC clone in lanes 2-5 (pattern A) and the other given by the BAC clone in lane 6 (pattern B). This gel was blotted and hybridized sequentially to a series of probes.

Probe $\mathrm{Bz}-528$ from $\mathrm{Bz}-\mathrm{McC}$ hybridized to a $90-\mathrm{kb}$ band-the largest NotI fragment-in lanes 2-5 and to a 10-kb band in lane 6 (Fig. 4B). The common band seen at $8 \mathrm{~kb}$ in all $\mathrm{BAC}$ lanes is due to nonspecific hybridization of the $B z-528$ probe to the BAC vector. Sixteen of the seventeen positive clones gave pattern A upon digestion with Not I. We suspected that these corresponded to the distal $B z-M c C$ fragment because most of the $B z$ probe used in the screen hybridizes to the distal NotI fragment as a consequence of the asymmetric location of its internal NotI site. This suspicion was confirmed when the membrane was hybridized to probe STC-323, corresponding to a sesquiterpene cyclase (B. Shen, Z. Zheng, and H.K. Dooner, unpubl.), located 5 $\mathrm{kb}$ distal to the NotI site in Bz-McC (Fig. 3). As seen in Figure 4C, probe STC-323 detects the same $90-\mathrm{kb}$ band as the $B z$ probe in lanes $2-5$, but does not hybridize to any NotI fragments in lane 6 . To confirm that the BAC in lane 6 contains the proximal NotI fragment, the membrane was hybridized with a probe from tac2094, a locus that maps $0.05 \mathrm{cM}$ proximal to $\mathrm{Bz}$ (Dooner and Belachew 1989). tac2094 corresponds to the site of insertion of Ac2094, a transposed Ac element from the bz-m2(Ac) allele. The tac2094 site has been cloned and sequenced and shown to correspond to unique DNA (Ralston et al. 1989). Because tac2094 hybridized to the same band as a Bz probe in NotI genomic digests (Fig. $2 \mathrm{~B}$ and data not shown), we expected that it would also hybridize to the proximal BAC clone, and it did. As seen in Figure 4D, tac2094 detects a band of about 63 $\mathrm{kb}$ in lane 6 , but does not hybridize to any NotI fragments in the other lanes. In an attempt to isolate additional clones of the proximal $B z-M c C$ fragment, the library was rescreened with the proximal tac2094 probe. Nine additional clones were obtained from this screen, and all gave the same B pattern of fragments upon digestion with NotI. Thus, several clones of both $B z-M c C$ NotI fragments were recovered from the partial BAC library.

Both types of BACs contained other NotI fragments besides the ones hybridizing to the $B z$ probe, indicating that the cloned NotI genomic fragments 


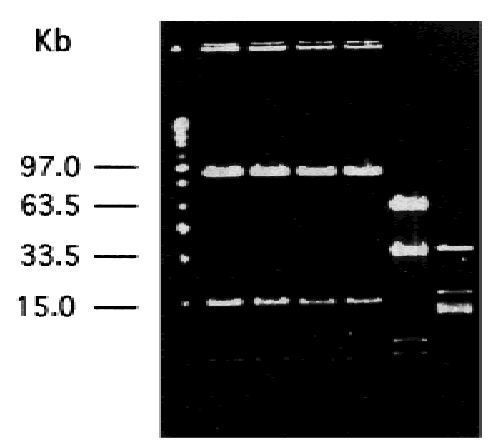

A

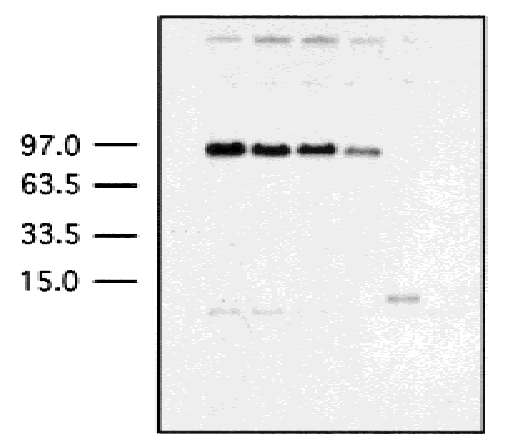

B

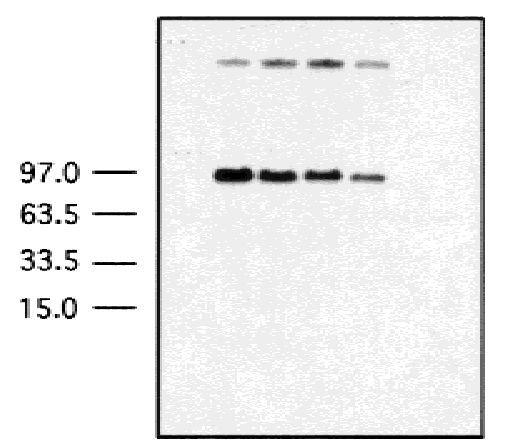

C

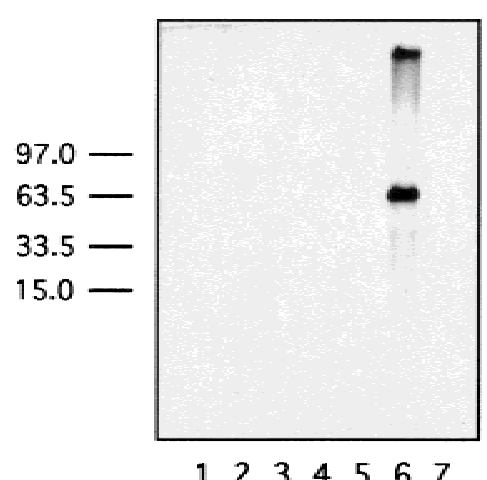

1234567

Figure 4 Analysis of $B A C$ clones that hybridized to the probe $B z-528$. BAC DNA from positive clones was extracted, digested with Notl, and separated by CHEF gel electrophoresis. $(A)$ Ethidium bromide-stained gel containing DNA from five positive clones (lanes 2-6), one negative clone (lane 7), and highmolecular-weight markers (lane 1). The gel was transferred to a nylon membrane and hybridized successively with three different probes, as shown in $B-D$. (B) Hybridization with probe $B z-528$; (C) hybridization with probe STC-323, distal to $B z ;(D)$ hybridization with a tac2094 probe, proximal to $B z$. have internal NotI sites that are not cleaved by the enzyme because they are probably methylated. The BACs producing the A pattern of NotI fragments have an $18-\mathrm{kb}$ NotI fragment, in addition to the $90-\mathrm{kb}$ fragment, that hybridized to both the Bz and STC-323 probes. Thus, the overall size of the insert in the BAC containing the distal NotI fragment from $\mathrm{Bz}-\mathrm{McC}$ is 108 $\mathrm{kb}$. Because $B z$ defines the proximal end of the insert, the $90-\mathrm{kb}$ NotI fragment must lie proximal to the $18-\mathrm{kb}$ fragment in the chromosome. The BACs producing the B pattern have NotI fragments of 40,5 , and $3 \mathrm{~kb}$, in addition to the 10-kb, Bz-hybridizing fragment and the 63-kb, tac2094-hybridizing fragment. Thus, the overall size of the insert in the BAC containing the proximal NotI fragment from $\mathrm{Bz}-\mathrm{McC}$ is $121 \mathrm{~kb}$. Except for the Bz-hybridizing fragment, which must lie at the distal end of the BAC clone, we do not know at this point the relative order of the NotI fragments in the proximal $\mathrm{BAC}$, but we are currently in the process of characterizing the physical organization of both BACs vis-á-vis the genetic organization of the $\mathrm{Bz}$ region.

\section{Further Characterization of the Partial BAC Library}

The methylation-sensitive NotI enzyme should cut maize DNA in and close to genes. Thus, our NotI partial BAC library can be expected to be enriched for genic DNA. To determine whether the library could be used to isolate large fragments from other well-characterized genes, we screened the library with five different pobes: wx (Varagona et al. 1992), an enod93 homolog (W. Park and H.K. Dooner, unpubl.), tub4 (Villemur et al. 1994), $R$ (Ludwig et al. 1989), and sh2 (Bhave et al. 1990).

Southern blot data indicated that the NotI fragments containing the tub4 and $R$ genes should be present in the 100 - to $180-\mathrm{kb}$ size fraction used to construct our BAC library, but that the NotI fragments containing the $w x$, enod93, and sh2 genes are either too small or too large to be present in the library (Fig. 5). In agreement with this expectation, we succeeded in isolating six 140-kb tub4 and two $180-\mathrm{kb} R$ clones from the partial BAC library (Fig. 6). These BAC clones are present in ninefold and threefold excess, respectively, confirming that the Not I partial BAC library has a disproportionate representation of chromosome fragments containing genes and is, thus, a valuable source of high-molecular-weight genic DNA from maize. It should be possible to recover large NotI BAC clones of $w x$ and enod93 from a similar size fractionation of a NotI partial digest and a sh2 clone from a larger size fraction of a complete NotI digest, although the sh2 NotI fragment $(300 \mathrm{~kb})$ is close to the upper limit of the size normally cloned into BAC vectors.

To assess the composition of our partial BAC library, 70 random clones were analyzed. Of the 70 clones, 67 (>95\%) had inserts. The clone insert size 


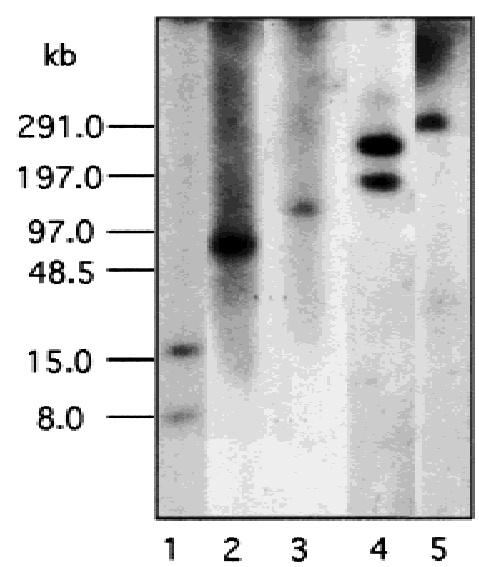

Figure 5 Southern blot analysis of high-molecular-weight maize genomic DNA. High-molecular-weight DNA was digested with Notl, separated by CHEF gel electrophoresis, and hybridized to different cDNA probes. (Lane 1) wx; (lane 2) enod93; (lane 3) tub4; (lane 4) R; (lane 5) sh2.

averaged $106 \mathrm{~kb}$ and ranged from 60 to $180 \mathrm{~kb}$. The identical makeup of the 16 distal and 10 proximal $\mathrm{Bz}$ $M c C$ clones, of the six tub4 clones, and of the two $R$ clones suggests that there is little or no chimerism in the library.

\section{DISCUSSION}

Here, we report the BAC cloning of large, allele-specific genomic fragments from a partial BAC library of the maize inbred line W22. The library was constructed for the specific cloning of two adjacent, $>100-\mathrm{kb}$ NotI fragments from the $B z-M c C$ allele present in that line. Several clones of both fragments were recovered, as well as two clones of the $R-r$ allele carried in that line (Dooner and Kermicle 1971) and six clones of the tub4 gene

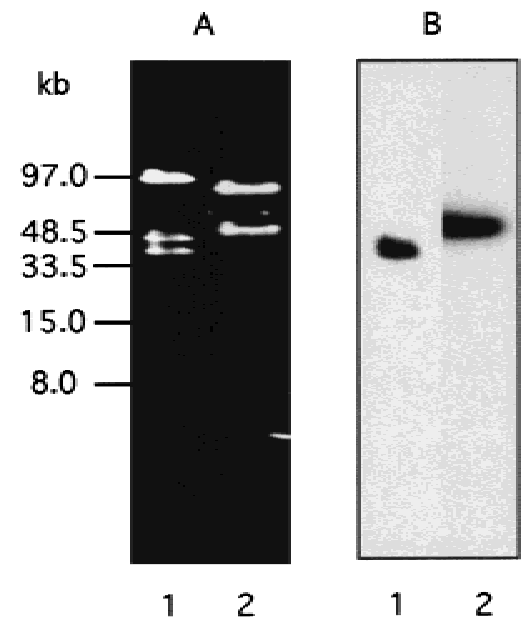

Figure 6. Analysis of $R$ and tub4 BAC clones. BAC DNA was extracted, digested with Notl, and separated by CHEF gel electrophoresis. $(A)$ Ethidium bromide-stained gel. (Lane 1) $R$ clone; (lane 2) tub4 clone. (B) Autoradiogram of the gel blot in $A$ hybridized to $R$ cDNA (lane 1) and tub4 cDNA (lane 2).
(Villemur et al. 1994), which also produce large fragments upon NotI digestion. This study constitutes the first example of targeted BAC cloning of allele-specific genomic fragments from a plant with a large genome and illustrates the feasibility of this approach when the construction of a complete BAC library is not warranted. This approach should be particularly applicable to the cloning of loci consisting of clustered gene families in which the members of the family either exhibit high line-to-line polymorphism or contain uniquely interesting variants. Examples of the former are the $R p 1$ locus for resistance to races of the maize rust fungus (Hulbert and Bennetzen 1991; Richter et al. 1995) and the $R$ and $P$ loci that encode transcriptional regulators of anthocyanin biosynthesis in maize (Robbins et al. 1991; Eggleston et al. 1995; Chopra et al. 1998); an example of the latter is the $\alpha$-zein cluster of the maize inbred line BSSS53, which contains a dzr variant that conditions high methionine accumulation in the endosperm (Chaudhuri and Messing 1995; Llaca and Messing 1998).

In this work, we have shown that it is possible, without a huge commitment of resources, to clone specific large fragments of DNA from a particular inbred line of maize, a plant with well-known limitations for genomic analysis because of its large genome. So far, only two maize lines (B73 and LH132) have been used to construct BAC libraries. These are complete BAC libraries constructed by researchers in specialized centers in both the public and the private sectors (R. Wing, pers. comm. and http://www.genome.clemson.edu/ lib_frame.html; Genome Systems, Inc.). As geneticists with a long-term interest in the relationship between genetic and physical distance inside and outside of the $\mathrm{Bz}$ gene, we wanted to isolate large DNA fragments of the $B z$ region from the specific line where we had conducted all our previous studies on intergenic recombination. That line is a color-converted version of the inbred line W22 that carries an introgressed Bz-McC allele (Dooner and Belachew 1989). Early on, we learned that the region immediately distal to the $B z$ locus differed in B73 and in our line (H. Fu and H.K. Dooner, unpubl.), so it became essential for us to isolate BAC clones of our own line. We developed a strategy and a vector to accomplish this task and, in less than four months, succeeded in isolating multiple clones of the desired region from a partial BAC library containing less than one genome's worth of maize DNA. Our present success should encourage others who may want to isolate large allele-specific genomic fragments to pursue a similar strategy.

Southern blot analysis of $B z-M c C$ DNA digested with the methylation-sensitive enzyme NotI and separated by CHEF gel electrophoresis revealed two Bzhybridizing fragments of about $110 \mathrm{~kb}$ each. Maize genes exist in regions of hypomethylated DNA (Ante- 
quera and Bird 1988; Bennetzen et al. 1994), so it is not surprising that the internal NotI site of $B z-M c C$ (Ralston et al. 1988) is cleaved by NotI. Because NotI recognizes an 8-bp restriction site and is sensitive to cytosine methylation, restriction of genomic DNA with NotI, followed by size fractionation of the digested DNA should result in a very significant enrichment of large DNA fragments containing genes. To clone these NotI fragments, we converted pBeloBAC 11 into a NotI cloning vector (pNOBAC 1) and ligated NotI fragments in the 100 - to $180-\mathrm{kb}$ range to the new vector. From a library of about 20,000 BACs, containing a total amount of DNA equivalent to approximately twothirds of a maize genome, we isolated 16 BAC clones of the 110-kb distal and 10 BAC clones of the 130-kb proximal $\mathrm{Bz}$ fragments. This recovery means that our strategy resulted in a 15- to 24 -fold enrichment of specific sequences.

To show the general utility of our approach and the value of our partial BAC library, we also set out to isolate BAC clones of tub4 and $R$, two genes that should be present in the library based on the size of their respective NotI fragments. The complex $R$ - $r$ allele in our line contains three copies of the $R$ coding sequence, designated $P, S 1$, and $S 2$ (Robbins et al. 1991), within a stretch of about $190 \mathrm{~kb}$ (Walker et al. 1995). We succeeded in isolating two identical 180-kb BAC clones of $R-r$ and six identical 140-kb tub4 clones. The lower recovery of $R-r$ and tub4 clones relative to $B z-M c C$ clones can be explained by their larger size. Not only are larger fragments harder to clone, but the $180-\mathrm{kb} R$ insert is at the high end of the size fractionation range used in the construction of the library. The insert size in the resulting BAC library ranged from 60 to $180 \mathrm{~kb}$ and averaged $106 \mathrm{~kb}$.

The large 240-kb BAC contig of the Bz-McC allele was assembled from DNA completely digested with NotI. We took advantage of an internal NotI site in the previously cloned $B z-M c C$ allele (Ralston et al. 1988) to define the contig junction, instead of basing the assembly on the sequences of overlapping BAC clones obtained from incompletely digested genomic DNA. Thus, the occurrence of a cleavable internal NotI site allows a very efficient use of a partial library in assembling a contig. All four classes of BAC clonesthe proximal and distal $\mathrm{Bz}-\mathrm{McC}$ clones, the tub4 clones, and the $R-r$ clone-contained internal NotI sites, confirming that many NotI sites in maize genomic DNA are not cleaved because they are probably methylated. The presence of internal NotI sites in the BAC clones allows a quick assessment of clone identity. All 16 distal Bz-McC clones had an identical NotI fragment makeup, as did all 10 proximal $\mathrm{Bz}-\mathrm{McC}$ clones, the six tub4 clones, and both $R-r$ clones, suggesting that there is little or no chimerism in our NotI BAC library.

\section{METHODS}

\section{Plant Material}

The maize stock used in this study carried the $B z-M c C$ allele introgressed into the genetic background of the inbred W22. This is the normal progenitor allele of the $b z-m 2(A c)$ mutation (McClintock 1955), which served as the donor locus of many transposed Ac elements (trAcs) that have been used as markers in recombination experiments (Dooner and Belachew 1989).

\section{Preparation of High-Molecular-Weight DNA from Maize}

High-molecular-weight DNA was extracted from the shoots and leaves of 4-week-old greenhouse-grown maize plants, as described (Wang et al. 1995; Yang et al. 1997) with some modifications. About 50 grams of tissue was used for nuclear isolation. The tissue was washed with tap water and ground manually to a fine powder in liquid nitrogen. The powder was suspended in $200 \mathrm{ml}$ of ice-cold $1 \times \mathrm{GH}$ buffer $(1 \mathrm{~mm}$ spermidine, $1 \mathrm{~mm}$ spermine, $10 \mathrm{~mm} \mathrm{Na}_{2}$-EDTA, $10 \mathrm{~mm}$ Tris, $80 \mathrm{~mm}$ $\mathrm{KCl}, 0.5 \%$ Triton-X $100,0.15 \% \beta$-mercaptoethanol, and $0.5 \mathrm{M}$ sucrose at $\mathrm{pH}$ 9.4-9.5). After incubation in ice for $20 \mathrm{~min}$, the suspension was filtered by squeezing with gloved hands through four layers of cheesecloth into a pre-chilled centrifuge bottle. The filtrate was centrifuged at $1800 \mathrm{~g}$ (Beckman model JA14, maximum speed, $3500 \mathrm{rpm}$ ) for $20 \mathrm{~min}$ at $4^{\circ} \mathrm{C}$. Then, the supernatant was discarded, and the nuclei pellet was resuspended in $30 \mathrm{ml}$ of $1 \times \mathrm{GH}$ buffer. The resuspended nuclei were filtered by gravity through two layers of Miracloth (Calbiochem) and spun down at $1800 \mathrm{~g}$ for $15 \mathrm{~min}$ at $4^{\circ} \mathrm{C}$. The resulting nuclei pellet was washed three times with $1 \times \mathrm{GH}$ buffer, resuspended in $1.5 \mathrm{ml} 1 \times \mathrm{GH}$ buffer without $\beta$-mercaptoethanol and embedded in an equal volume of $2 \%$ lowmelting-point agarose. Plugs containing about 5-8 $\mu \mathrm{g}$ DNA in a volume of $80 \mu \mathrm{l}$ were lysed in $30 \mathrm{ml}$ of lysis buffer (0.5 M EDTA, $1 \%$ sodium lauryl sarcosine, $2 \mathrm{mg} / \mathrm{ml}$ proteinase $\mathrm{K}$, at $\mathrm{pH} 9.3-$ 9.4) for $48 \mathrm{hr}$ at $50^{\circ} \mathrm{C}$, with one change of buffer after $24 \mathrm{hr}$.

\section{Digestion of High-Molecular-Weight DNA and Size Fractionation by Pulsed-Field Gel Electrophoresis}

After lysis, the agarose plugs were washed once in $0.5 \mathrm{M}$ EDTA (pH 9.3) for $1 \mathrm{hr}$ at $50^{\circ} \mathrm{C}$, dialyzed four times against TE buffer (10 mm Tris, 1 mm EDTA, at pH 8.0) containing $1 \mathrm{~mm}$ phenylmethyl sulfonylfluoride (PMSF) for $1 \mathrm{hr}$ at $4^{\circ} \mathrm{C}$ with gentle shaking, and equilibrated twice with NotI buffer for $1 \mathrm{hr}$ at $4^{\circ} \mathrm{C}$. Sixty units of NotI were added per plug and the enzyme was allowed to diffuse into the plug for $1 \mathrm{hr}$ on ice. Complete digestion was achieved by incubating at $37^{\circ} \mathrm{C}$ for $10 \mathrm{hr}$. The digested DNA in four plugs was loaded into a $1 \%$ gel made with pulsed-field certified agarose (Bio-Rad) and fractionated by pulsed-field gel electrophoresis (CHEF-DR II system, BioRad). The digested DNA was resolved in three steps as described previously (Osoegawa et al. 1998), with some modifications. The first step allowed the DNA to migrate from the wells toward the nearest gel edge (about $1 \mathrm{~cm}$ away from the well). Small DNA fragments were electrophoresed out of the gel by running it at $14^{\circ} \mathrm{C}$ and $6 \mathrm{~V} / \mathrm{cm}$ for $3 \mathrm{hr}$ with a $15 \mathrm{sec}$ pulse time. In the second step, the direction of the gel was changed back to normal, and the gel was run under the same conditions as in step 1 to bring all the fragments remaining in the gel back to the well. Finally, the fragments were resolved at $6 \mathrm{~V} / \mathrm{cm}$ for $16 \mathrm{hr}$ with a $0.1-$ to $40-\mathrm{sec}$ pulse time. The section of the agarose gel containing DNA fragments between 
100 and $180 \mathrm{~kb}$ was cut out, and the fragments were recovered by electroelution.

\section{Vector Modification}

The polylinker of pBeloBAC 11 has HindIII and BamHI cloning sites (Kim et al. 1996a). To add NotI cloning capability to the vector, the following modifications were performed. A NotI site was added to the polylinker of pBeloBAC 11 by sitedirected mutagenesis with the 40-bp oligonucleotide CCTCTAGAGTCGACCTGCGGCCGCGCAAGCTTGAGTATTC and the two NotI sites flanking the polylinker were eliminated by cutting the vector with NotI and filling in with the Klenow fragment of DNA polymerase. The modified vector, pNOBAC 1, has one NotI site between BamHI and HindIII in the polylinker and retains all the functions of pBeloBAC 11 (Fig. 1 ), including the blue-white selection feature on X-gal. It is available from the authors upon request.

\section{Preparation of Vector, Ligation, and Transformation}

Vector DNA was isolated as described previously (Wang et al. 1995) with some modifications. Briefly, a single colony of pNOBAC 1 was cultured overnight in $30 \mathrm{ml}$ of LB containing $30 \mu \mathrm{g} / \mathrm{ml}$ of chloramphenicol at $37^{\circ} \mathrm{C}$ with shaking at 250 $\mathrm{rpm}$. A 30-ml aliquot of the overnight culture was diluted in 5 liters of LB containing $30 \mu \mathrm{g} / \mathrm{ml}$ of chloramphenicol and incubated at $37^{\circ} \mathrm{C}$ for $12 \mathrm{hr}$. The plasmid DNA was isolated by alkali lysis and purified by CsCl-ethidium bromide differential centrifugation (Sambrook et al. 1989). Purified pNOBAC 1 DNA was digested with NotI, dephosphorylated with CIP (New England Biolabs), and used for ligation.

Size-fractionated and electroeluted genomic DNA was ligated to $50 \mathrm{ng}$ of NotI-digested and dephosphorylated pNOBAC 1 DNA at an 1:5 to 1:10 molar ratio of insert:vector in a $50-\mu$ l total volume with 1 unit of T4 DNA ligase (Promega) at $16^{\circ} \mathrm{C}$ for $8-10 \mathrm{hr}$. The reaction was placed on a $25-$ $\mathrm{mm}, 0.025-\mu \mathrm{m}$ pore size microdialysis filter (Millipore) and allowed to dialyze passively, first against sterile deionized water on ice for $2-3 \mathrm{hr}$ and then against $0.5 \times$ TE containing $30 \%$ PEG 8000 (Sigma) on ice for $0.5-1$ hr to reduce the volume to about $20 \mu \mathrm{l}$ before transformation. Two microliters of ligation reaction was used to transform $40 \mu$ lectroMAX DH 10B competent cells (Life Technologies) by electroporation with a Gene Pulser II (Bio-Rad). The electroporation conditions were $2.5 \mathrm{KV}, 25 \mu \mathrm{F}, 100 \Omega$, and a $0.1-\mathrm{cm}$ cuvette. After the electroporation, the cells were immediately added to $1 \mathrm{ml}$ of SOC medium (Sambrook et al. 1989) and incubated at $37^{\circ} \mathrm{C}$ for $1 \mathrm{hr}$ by shaking at $250 \mathrm{rpm}$ to express the antibiotic resistance gene. The cells were then plated on LB plates $(100 \times 15 \mathrm{~mm})$ containing $20 \mu \mathrm{g} / \mathrm{ml}$ chloramphenicol, $5 \mu \mathrm{g}$ of X-gal and 100 $\mu \mathrm{g} / \mathrm{ml}$ of IPTG, and incubated at $37^{\circ} \mathrm{C}$ for $24 \mathrm{hr}$ to a colony diameter of $1-2 \mathrm{~mm}$. These plates were used in the primary screen.

\section{Screening and Analysis of the BAC Partial Library}

Bacterial colonies were transferred to Hybond-N+ nylon membranes (Amersham), hybridized with a $\mathrm{Bz}$ radioactive probe, and washed at high stringency following the manufacturer's instructions. Probes were labeled by use of random primer extension. The washed membranes were exposed to $\mathrm{X}$-ray film overnight to reveal positive clones. Seventeen colonies giving the strongest signals were picked, and all turned out to be positive upon subsequent testing.

The bacterial colonies from the plates used in the primary screen $(\sim 20,000)$ were transferred individually to a series of 384-well microtiter plates for long-term storage. The colonies were replica-plated onto Hybond-N+ nylon membranes, and the membranes were hybridized with a tac2094 probe (Ralston et al. 1989) to isolate additional BAC clones of the NotI fragment on the proximal side of $B z-M c C$ and with several maize cDNA probes to isolate BAC clones of other maize genes (see Results).

Restriction enzyme digestion and genomic blotting were carried out as described (Dooner et al. 1985).

\section{ACKNOWLEDGMENTS}

We thank Zhenwei Zheng for unpublished observations and Victor Llaca and Xianghe Yan for comments on the manuscript. The project was supported by grants from the National Science Foundation (MCB 96-30358 and MCB 99-04646) to H.K.D.

The publication costs of this article were defrayed in part by payment of page charges. This article must therefore be hereby marked "advertisement" in accordance with 18 USC section 1734 solely to indicate this fact.

\section{REFERENCES}

Antequera, F. and A.P. Bird. 1988. Unmethylated CpG islands associated with genes in higher plant DNA. EMBO J. 7: 2295-2299.

Arumuganathan, K. and E.D. Earle. 1991. Nuclear DNA content of some important plant species. Plant Mol. Biol. Reporter 9: 208-218.

Bennetzen, J.L., K. Schrick, P.S. Springer, W.E. Brown and P. SanMiguel. 1994. Active maize genes are unmodified and flanked by diverse classes of modified, highly repetitive DNA. Genome 37: 565-576.

Bhave, M.R., S. Lawrence, C. Barton, and L.C. Hannah. 1990. Identification and molecular characterization of shrunken 2 cDNA clones of maize. Plant Cell 2: 581-588.

Budiman, M.A., J.P. Tomkins and R.A. Wing. 1999. Construction and characterization of rice Nipponbare BAC library. URL: http://www.genome.clemson.edu / rice_frame.html.

Chaudhuri, S. and J. Messing. 1995. RFLP mapping of the maize dzr1 locus, which regulates methionine-rich $10 \mathrm{kDa}$ zein accumulation. Mol. Gen. Genet. 246: 707-715.

Chopra, S., P. Athma, X.-G. Li and T. Peterson. 1998. A maize Myb homolog is encoded by a multicopy gene complex. Mol. Gen. Genet. 260: 372-380.

Dooner, H.K. 1986. Genetic fine structure of the bronze locus in maize. Genetics 113: 1021-1036.

Dooner, H.K., and A. Belachew. 1989. Transposition pattern of the maize element $A c$ from the $b z-m 2(A c)$ allele. Genetics 122: $447-457$.

Dooner, H.K. and J.L. Kermicle. 1971. Structure of the R-r tandem duplication in maize. Genetics 67: 427-436.

Dooner, H.K. and I.M. Martinez-Ferez. 1997. Recombination occurs uniformly within the bronze locus, a meiotic recombination hotspot in the maize genome. Plant Cell 9: 1633-1646.

Dooner, H.K., E. Weck, S. Adams, E. Ralston, M. Favreau, and J. English. 1985. A molecular genetic analysis of insertion mutations in the bronze locus in maize. Mol. Gen. Genet. 200: $240-246$.

Eggleston, W.B., M. Alleman and J.L. Kermicle. 1995. Molecular organization and germinal instability of R-stippled maize. Genetics 141: 347-360.

Hake, S. and V. Walbot. 1980. The genome of Zea mays, its organization and homology to related grasses. Chromosoma 79: 251-270.

Hamilton, C.M. 1997. A binary-BAC system for plant transformation with high-molecular-weight DNA. Gene 200: 107-116.

Hulbert, S.H. and J.L. Bennetzen. 1991. Recombination at the Rp1 locus of maize. Mol. Gen. Genet. 226: 377-382. 
Kim, U.J., B.W. Birren, T. Slepak, V. Mancino, C. Boysen, H.L. Kang, M.I. Simon, and H. Shizuya. 1996a. Construction and characterization of a human bacterial artificial chromosome library. Genomics 34: 213-218.

Kim, U.J., H. Shizuya, H.L. Kang, S.S. Choi, C.L. Garrett, L.J. Smink, B.W. Birren, J.R. Korenberg, I. Dunham, and M.I. Simon. 1996b. A bacterial artificial chromosome-based framework contig map of human chromosome 22q. Proc. Natl. Acad. Sci. 93: 6297-6301.

Llaca, V. and J. Messing. 1998. Amplicons of maize zein genes are conserved within genic but expanded and constricted in intergenic regions. Plant J. 15: 211-220.

Ludwig, S.R., L. Habera, S.L. Dellaporta, and S. Wessler. 1989. Lc, a member of the maize $R$ gene family responsible for tissue-specific anthocyanin production, encodes a protein similar to transcription factors and contains the myc-homology region. Proc. Natl. Acad. Sci. 86: 7092-7096.

McClintock, B. 1955. Controlled mutation in maize. Carnegie Inst. Wash. Yrbk. 54: 245-255.

Mozo, T., S. Fischer, H. Shizuya, and T. Altmann. 1998. Construction and characterization of the IGF Arabidopsis BAC library. Mol. Gen. Genet. 258: 562-570.

Osoegawa, K., P.Y. Woon, B. Zhao, E. Frengen, M. Tateno, J.J. Catanese, and P.J. deJong. 1998. An improved approach for construction of bacterial artificial chromosome libraries. Genomics 52: 1-8.

Ralston, E.J., J. English, and H.K. Dooner. 1988. Sequence of three bronze alleles of maize and correlation with the genetic fine structure. Genetics 119: 185-197.

- 1989. Chromosome-breaking structure in maize involving a fractured Ac element. Proc. Natl. Acad. Sci. 86: 9451-9455.

Richter, T.E., T.J. Pryor, J.L. Bennetzen, and S.H. Hulbert. 1995. New rust resistance specificities associated with recombination in the Rp1 complex in maize. Genetics 141: 373-381.

Robbins, T.P., E.L. Walker, J.L. Kermicle, M. Alleman, and S.L. Dellaporta. 1991. Meiotic instability of the $R-r$ complex arising from displaced intragenic exchange and intrachromosonal rearrangement. Genetics 129: 271-283.

Sambrook, J., E.F. Fritsch, and T. Maniatis. 1989. Molecular cloning: A laboratory manual. Cold Spring Harbor Laboratory Press, Cold Spring Harbor, NY.

Shizuya, H., B. Birren, U.-J. Kim, V. Mancino, T. Slepak, Y. Tachiiri, and M.I. Simon. 1992. Cloning and stable maintenance of 300-kb fragments of human DNA in E. coli using an F-factor based vector. Proc. Natl. Acad. Sci. 89: 8794-8797.

Tomkins, J.P., R. Mahalingham, W. Smith, J.L. Goicoechea, H.T. Knap, and R.A. Wing. 1999a. A BAC library for soybean PI 437654 and identification of clones associated with cyst nematode resistance. Plant Mol. Biol. 41: 25-32.

Tomkins, J.P., Y. Yu, H. Miller-Smith, D.A. Frisch, S.S. Woo, and R.A. Wing. 1999b. A bacterial artificial chromosome library for sugarcane. Theor. Appl. Genet. 99: 419-424.

Varagona, M.J., M. Purugganan, and S.R. Wessler. 1992. Alternative splicing induced by insertion of retrotransposons in the maize waxy gene. Plant Cell 4: 811-820.

Villemur, R., N.A. Haas, C.M. Joyce, D.P. Snustad, and C.D. Silflow. 1994. Characterization of four new beta-tubulin genes and their expression during male flower development in maize. Plant Mol. Biol. 24: 293-315.

Walbot, V. and J. Messing. 1988. Molecular genetics of corn. In Corn and corn improvement (ed. G.F. Sprague and J.W. Dudley), pp. 389-429 American Society of Agronomy, Madison, WI.

Walker, E.L., T.P. Robbins, T.E. Bureau, J. Kermicle, and S.L. Dellaporta. 1995. Transposon-mediated chromosomal rearrangements and gene duplications in the formation of the maize $R-r$ complex. EMBO J. 14: 2350-2363.

Wang, G.L., T.E. Holsten, W.Y. Song, H.P. Wang, and P.C. Ronald. 1995. Construction of a rice bacterial artificial chromosome library and identification of clones linked to the Xa-21 disease resistance locus. Plant J. 7: 525-533.

Woo, S.S., J. Jiang, B.S. Gill, A.H. Paterson, and R.A. Wing. 1994. Construction and characterization of a bacterial artificial chromosome library of Sorghum bicolor. Nucleic Acids Res. 22: 4922-4931.

Xu, J., D. Yang, J. Domingo, J. Ni, and N. Huang. 1998. Screening for overlapping bacterial artificial chromosome clones by PCR analysis with an arbitrary primer. Proc. Natl. Acad. Sci. 95: 5661-5666.

Yang, D., A. Parco, S. Nandi, P. Subudhi, Y. Zhu, G. Wang, and N. Huang. 1997. Construction of a bacterial artificial chromosome (BAC) library and identification of overlapping BAC clones with chromosome 4-specific RFLP markers in rice. Theor. Appl. Genet. 95: $1147-1154$.

Received November 29, 1999; accepted in revised form April 19, 2000.
Genome Research www.genome.org 


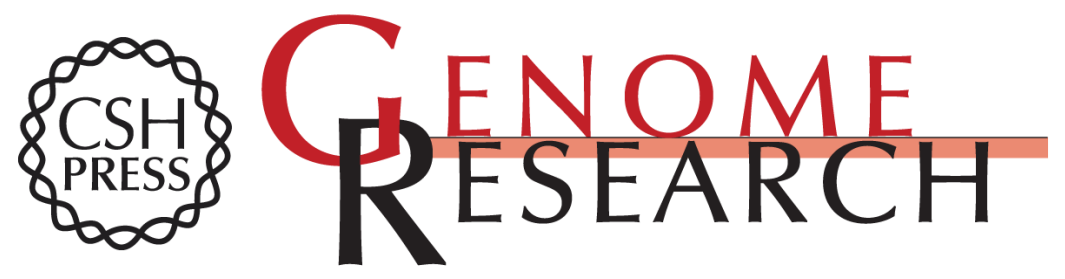

\section{A Gene-enriched BAC Library for Cloning Large Allele-specific Fragments from Maize: Isolation of a $240-\mathrm{kb}$ Contig of the bronze Region}

Huihua Fu and Hugo K. Dooner

Genome Res. 2000 10: 866-873

Access the most recent version at doi:10.1101/gr.10.6.866

References This article cites 34 articles, 15 of which can be accessed free at:

http://genome.cshlp.org/content/10/6/866.full.html\#ref-list-1

\section{License}

Email Alerting

Receive free email alerts when new articles cite this article - sign up in the box at the Service top right corner of the article or click here.

\section{Affordable, Accurate Sequencing.}

\section{gencove}

To subscribe to Genome Research go to: https://genome.cshlp.org/subscriptions 